\title{
Effect of Genistein-Enriched Diets on the Endocrine Process of Gametogenesis and on Reproduction Efficiency of the Rainbow Trout Oncorhynchus mykiss
}

\author{
Catherine Bennetau-Pelissero ${ }^{\text {ba }}{ }^{*}$, Bernard Breton ${ }^{c}$, Bernard Bennetau $^{d}$, Geneviève Corraze ${ }^{e}$, \\ Françoise Le Menn ${ }^{\mathrm{b}}$, Blandine Davail-Cuisset ${ }^{\mathrm{b}}$, Chantal Helou ${ }^{\mathrm{b}}$ \\ and Sadasivam J. Kaushik
}

\footnotetext{
${ }^{a}$ ENITA de Bordeaux, 1 Cours du Général de Gaulle, B.P. 201, 33175, Gradignan, France

${ }^{b}$ Laboratoire de Biologie de la Reproduction des Poissons, Université Bordeaux I, Avenue des Facultés, 33405 , Talence, France

'Laboratoire de Physiologie des Poissons, INRA, Université de Rennes I, 35042, Rennes, France

d Laboratoire de Chime Organique et Organométallique, UMR 5802 CNRS, Université Bordeaux I, 351 Cours de la Libération, 33405, Talence, France

'Laboratoire de Nutrition des Poissons, Unité Mixte INRA-IFREMER, 64310, Saint Pée sur Nivelle, France
}

\begin{abstract}
*: Corresponding author : To whom correspondence and reprint requests should be addressed at the Research Department, Unit Micronutriments, Reproduction, Health 1, Cours du Général de Gaulle, B.P. 201, F33175, Gradignan, France. Fax: 00335573507 59. E-mail: c-bennetau@enitab.fr.
\end{abstract}

\begin{abstract}
Three practical diets were formulated to contain 0, 500, or 1000 ppm genistein. The three diets were distributed for 1 year to groups of rainbow trout undergoing their first gametogenesis and until spawning. Growth performance of rainbow trout was not affected by dietary treatments. Plasma cholesterol levels were equivalent between groups. In males, a slight but constant induction of vitellogenin (VTG) synthesis and a decrease in testosterone levels were observed. A slight decrease in plasma levels of $\beta F S H$ and $\beta \mathrm{LH}$ was noticed at the end of spermatogenesis in the male fish fed a diet with $500 \mathrm{ppm}$ (genistein) (from $2.16 \pm 0.39$ to $1.47 \pm 0.23$ for $\beta F S H$ and from $0.44 \pm 0.09$ to $0.31 \pm$ 0.09 for $\beta \mathrm{LH}$ ). There was a significantly reduced $17 \alpha, 20 \beta(\mathrm{OH}) 2$-progesterone (from $10.93 \pm 0.88$ in control to $5.46 \pm 0.92$ in males and from $251.22 \pm 21.40$ to $183.22 \pm 13.48$ in females). Testicular development was accelerated in genistein-fed fish, and sperm motility and concentration were decreased in a dose-dependent manner at spawning. In females, a significant increase in plasma VTG occurred only at the beginning and at the end of oogenesis. Testosterone levels were decreased at the beginning of oogenesis. Both $\beta F S H$ and $\beta \mathrm{LH}$ were decreased by genistein (from $6.38 \pm 1.55$ to $3.44 \pm 0.82$ for $\beta$ FSH and from $15.18 \pm 3.00$ to $6.93 \pm 0.99$ for $\beta$ LH in females), whereas spawning was delayed only in females fed the diet with $500 \mathrm{ppm}$ of genistein. Gamete quality was impaired only in this group, as underlined by a lower percentage of ovulating females (from 100 to $79 \%$ at the end of the trial), a lower fertilization rate, and a lower viability of fry. These results may be explained by the agonistic/antagonistic effect of genistein on estrogen function related to the tissue ratio between endogenous estrogens/genistein.
\end{abstract}

Keywords: genistein; trout; steroid; vitellogenin; GTH; reproduction; diet 
Genistein (genistein) is a phytoestrogen whose properties are numerous. It binds to the estradiol receptor (ER) in mammals (Martin et al., 1978) and fish (Latonnelle et al., 1999). It is an anti-oxidant (György et al., 1964) and a protein kinase C (PKC) and a protein tyrosine kinase (PTK) inhibitor (Osada et al., 1988 ; Akiyama et al., 1987). Soybean, widely used in animal and human nutrition is rich in phytoestrogens and especially in genistein. Numerous other vegetables are also known to contain such compounds (Farnsworth et al., 1975 ; Setchell, 1985). The estrogen agonist/antagonist effect of genistein is well known (Pike et al., 1999). This compound is known to bind to estradiol receptors in the uterus and to be uterotrophic (Hopper et al., 1998 ; Milligan et al., 1998). It prevents the full pituitary gonadotropin $(\mathrm{GTH})$ release (Hughes, 1988) and acts on sexual differentiation in mammals (Levy et al., 1995). Impairments of progesterone synthesis in vitro (Kaplanski et al., 1981) and in vivo (Awoniyi et al., 1998) by high doses of genistein are also reported. However very few data are available on the in vivo effects of administration of this compound during the entire reproductive cycle. When they exist they report studies on mammals and more precisely in rats (Awoniyi et al., 1998 ; Casanova et al., 1999) on in utero and neonatal exposures.

Trout (Oncorhynchus mykiss), a teleost fish, is a convenient model to assess this effect because of rather long gametogenesis normally lasting a year. Moreover its reproductive function has been thoroughly studied (Hoar et al., 1983) at a time when soy was not a major component of fish food. It offers the advantage of a late sexual differentiation at the fry stage whereas this developmental step occurs in utero in mammals. Even more, this development is much easier to monitor in reproducible conditions in a large number of individuals. Compared to mammals (Torbjorn, 1995), the degradation of xenobiotics is likely to be less important since the influence of the gut microflora is nil in this fish (Lesel, 1987). Indeed, it is known that daidzein can be transformed into equol by the gut microflora of many mammals including 
humans (Setchell and Cassidy, 1999) and that equol is about 10 times more estrogenic than daidzein (Pelissero et al., 1990). This particular situation is of interest when the estrogenic effect is approached. In addition, many tools are now available to assess the action of endocrine disruptors in this species. The estrogenicity of genistein in trout has already been demonstrated in vitro in hepatocyte cultures at both the transcriptional and posttranscriptional levels (Pelissero et al., 1993 ; Bennetau - Pelissero et al., 1998). Its binding to Steroid Binding Protein (SBP) has been studied in man (Martin et al., 1995) and in fish (Bennetau - Pelissero et al., 1998). In vitro, genistein used at high concentrations, acts as a low aromatase inhibitor in the ovary of rainbow trout (Pelissero et al., 1996).

The aim of the present study is to determine in vivo and, in rainbow trout over a full reproductive cycle, the effect of dietary genistein on the endocrine physiology and reproductive function. This long-term study was initiated to analyse the complex sequential effects of an endocrine disruptor upon the reproductive function and to provide baseline data for future work on the effects of genistein at the different levels of the estrogenic information steps. 


\section{MATERIAL AND METHODS}

\section{Fish.}

A mixed population of rainbow trout originating from our own stock (INRA) were used. They were 6-month-old and had a mean-weight of $40 \mathrm{~g}$ at the beginning of the experiment. They were allotted into 6 groups of 100 fish in 6 different tanks. Fish were grown at a constant water temperature of $17^{\circ} \mathrm{C} \pm 1{ }^{\circ} \mathrm{C}$ at the experimental fish farm (INRA, Donzacq, France) during the first part of the experiment. Three months before spawning they were transferred to another experimental fish farm (INRA, Lees Athas, France), and kept at a constant water temperature of $7^{\circ} \mathrm{C}$. They were maintained under natural light cycle during the whole experiment.

\section{Diets.}

Genistein (250 g) was obtained with an overall yield of $70 \%$, by a similar process described for daidzein (Pelissero et al., 1990) using phloroglucinol as starting material. The spectroscopic (NMR ${ }^{1} \mathrm{H}$ and ${ }^{13} \mathrm{C}$, IR) and physical data (CCM, melting point) fit those of the literature (Waltz, 1931 ; Baker et al., 1953 ; Pelter et al., 1978). Three practical diets with fish meal as the major protein source were prepared with three concentrations $(0,500$ and 1000 ppm) of genistein (see table 1). Diets were distributed ad libitum daily and twice a day to visual satiety. Fish were kept unfed for 36 hours before every sampling.

\section{Sample timing.}

The first sampling (T0) was 3 days before the beginning of the feeding trial. Then samples were withdrawn at about ten weeks intervals (figure 1).

\section{Blood samples.}


Fish were weighed at each sampling time, and each time 20 fish per tanks were killed by a sharp blow on the head for gonad examination. Blood samples were withdrawn from anaesthetised fish (ethylen glycol monophenyl ether $0.3 \%$ ) from the caudal vessels using an heparinized syringe. Blood was immediately transferred into heparinized vial stored on ice. And then centrifuged at $6000 \mathrm{~g}$ for 10 minutes plasma were stored at $-20^{\circ} \mathrm{C}$ until hormone measurements. At each sampling time, whole body, liver, gonad, and eviscerated body weight were recorded.

\section{Cholesterol analysis}

Plasma cholesterol analysis was performed on samples collected at T3 in July. Blood was withdrawn from the caudal vessels into heparinized tubes. Plasma was collected after centrifugation at $6000 \mathrm{~g}$ for $10 \mathrm{~min}$ and stored at $-20^{\circ} \mathrm{C}$ until analysed. Total plasma cholesterol was determined by colorimetric enzymatic method using a commercial kit (method CHOD-PAP, Boehringer Mannheim GmbH, Germany).

\section{Vitellogenin}

Plasma vitellogenin (VTG) levels were measured by a specific ELISA technique (Bon et al., 1997).

\section{Plasma concentration of steroid analysis.}

Testosterone $(\mathrm{T})$, estradiol $\left(\mathrm{E}_{2}\right)$ and 11-ketotestosterone $(11 \mathrm{KT})$ were monitored during the whole experiment. $17 \alpha, 20 \beta(\mathrm{OH})_{2}$-progesterone $\left(17 \alpha, 20 \beta(\mathrm{OH})_{2}-\mathrm{P}\right)$ was measured only at $\mathrm{T} 5$. Steroid analyses were performed on ethyl-acetate - cyclohexane (v-v) extracts from plasma samples (Fostier et al., 1979). Plasma 11-KT levels were measured according to Cuisset et al., (1995). $\mathrm{E}_{2}, \mathrm{~T}$ and $17 \alpha, 20 \beta(\mathrm{OH})_{2}-\mathrm{P}$ levels were measured using ELISAs raised on specific 
antibodies kindly donated by Dr Kime (University of Sheffield, UK), Dr Zanuy (CSIC Castellon, Spain) and Dr Fostier (INRA Rennes, France).

The technique is extensively described in (Cuisset et al., 1995).

\section{Gonadotrophins (GTHs)}

Plasma GTH1 (FSH) and GTH2 (LH) analysis were done by B. Breton (INRA, Rennes, France) according to the method described by Govorum et al. (1998).

\section{Histological analysis.}

Gonadal samples were examined histologically (Martojas and Martojas, 1967). The histological staining followed the Masson's trichrome technique. In females, 4 ovarian stages were identified whereas in males 5 stages were identified (see table 2). Gonad samples were analysed only from sampling times T0 to T3.

\section{Spawning.}

Individually identified (Spaghetti tag, COFA) fish were reared for 2 months before spawning in the experimental fish farm (INRA, Lees Athas, France) at a temperature of $7^{\circ} \mathrm{C}$. One and a half months before spawning, males were checked for spermiation. One month before spawning, females were checked weekly for ovulation. First ovulations started on the 22nd December and proceeded for a month and a half. Eggs and milt from the same dietary groups were used to produce progeny. Fish were weighed at spawning. Sperm was collected by stripping. Milt volume collected by stripping was measured in test tubes and motility assessed in water under a x40 magnification. Milt concentration was measured by spermatocrit measurement on a hematocrit rotor of a centrifuge Sigma 1-13. Females were stripped every week and selected on their ability to release their eggs. The date of spawning was recorded. 
Egg diameter, weight of ovulated egg, weight of 100 eggs and weight of residual gonad were recorded for each female at spawning. Fertilisation was performed mixing 500 eggs from a given female with $1 \mathrm{ml}$ of a mixture of milt from at least three males. It was diluted 1:30 with the INRA dilution mixture (Labbé and Maisse, 1996). After fertilisation, viability of the eggs, survival at day 1 and survival at embryo stage were recorded.

\section{Statistical analysis.}

After ANOVA, mean comparisons were made between the duplicate tanks and between the treatments. These tests were performed at each sampling time on the whole population and on the females and males separately. Mostly a $\mathrm{T}$ test was used and the acceptability threshold was fixed to $\alpha=0.05$. Sometimes, because of unequal sex ratio in the randomly harvested samples, a non parametric Kruskal-Wallis test was performed with the same significance threshold. These tests allowed the pooling the of fish from duplicate tanks since no significant difference was found at any time for any parameter. The frequency distributions were compared using the exact method of Fisher.

\section{RESULTS}

\section{Growth}

No incidence of dietary genistein levels was noted on fish weight during the whole experiment and no difference was noted between males and females. At the beginning of the experiment mean weight was $41.8 \pm 1.4 \mathrm{~g}$ and $40.8 \pm 2.0 \mathrm{~g}$ for male and female respectively. At the end of the trial mean male weights were $800.1 \pm 44.9,891.9 \pm 39.8$ and $852.8 \pm 29.3$ for $0,500 \mathrm{ppm}$ and $1000 \mathrm{ppm}$ genistein exposed fish respectively. Mean female weights were $753.9 \pm 28.2,802.1 \pm 31.1$ and $792.6 \pm 23.1$ for $0,500 \mathrm{ppm}$ and $1000 \mathrm{ppm}$ genistein fed fish respectively. 


\section{Cholesterol levels in plasma}

The analysis was performed on vitellogenic females and males undergoing spermiogenesis. No differences were recorded between treatments with the mean values $(\mathrm{ng} / \mathrm{ml}) \pm \mathrm{SEM}$ as follows : 0 ppm : $5.15 \pm 0.20(n=25) ; 500 \mathrm{ppm}: 5.71 \pm 0.35(\mathrm{n}=26) ; 1000 \mathrm{ppm}: 5.72 \pm 0.38$ $(n=31)$

\section{Steroids and VTG in males}

Control fish exhibited low levels of plasma estradiol $\left(\mathrm{E}_{2}\right)$ i.e. below $1 \mathrm{ng}$ per $\mathrm{ml}$ during the whole experiment except at T4 when the levels rose to $3.2 \mathrm{ng} / \mathrm{ml}$. The genistein-fed fish did not exhibit the same $\mathrm{E}_{2}$ increase (significant difference $\alpha=0.05$ ). At spawning time, (T5), there was still a significant difference although reduced (figure 2a).

As shown in figure $2 b$, dietary genistein significantly increased plasma VTG levels in males at all sampling times except T5. However, despite a 2 to 3 fold difference, the plasma VTG levels in the genistein-fed fish remained low $(<3 \mu \mathrm{g} / \mathrm{ml})$ compared to VTG levels in the females (figure $3 b$ ).

After a period during which the plasma testosterone (T) levels were below $5 \mathrm{ng} / \mathrm{ml} \mathrm{a}$ marked increase $(50 \mathrm{ng} / \mathrm{ml})$ was noted at $\mathrm{T} 4$ corresponding to the stage of full spermiogenesis in all groups. At T5, the plasma T levels decreased (figure 2c). Plasma T levels were always significantly lower in genistein-fed fish than in control except at T3 and T4 during spermatogenesis.

$11 \mathrm{KT}$ was the major androgen present during spermiogenesis. The plasma $11 \mathrm{KT}$ levels were generally not different between treatments; they were significantly lower in genistein-fed fish than in the control at $\mathrm{T} 1$ and $\mathrm{T} 5$ (spawning) where there was a significant dose-dependant decrease with increasing levels of genistein in the diet (figure $2 \mathrm{~d}$ ). 


\section{Steroids and VTG in females}

Until T2, plasma $E_{2}$ levels were initially below $1 \mathrm{ng} / \mathrm{ml}$. A slight increase occurred between $\mathrm{T} 2$ and $\mathrm{T} 3$ reaching $4 \mathrm{ng} / \mathrm{ml}$. Then, between $\mathrm{T} 3$ and $\mathrm{T} 4$, there was a marked increase up to $35 \mathrm{ng} / \mathrm{ml}$ during full vitellogenesis. At spawning, the plasma $\mathrm{E}_{2}$ levels decreased in all fish (figure 3a). There were no significant differences between control and treated fish at any time.

Plasma VTG levels in female trout started to increase from early vitellogenesis onwards $(<100 \mu \mathrm{g} / \mathrm{ml})$ to reach levels of $180 \mathrm{mg} / \mathrm{ml}$ by spawning. They were significantly higher in genistein-fed-fish at T2 (early vitellogenesis) and at T5 (spawning) (figure 3b).

Plasma $\mathrm{T}$ levels in fish fed with a diet containing $1000 \mathrm{ppm}$ of genistein diet were significantly lower than in control at the beginning of the experiment $(\mathrm{T} 1: \mathrm{KB} 1=0.45 \pm$ $0.11 ; \mathrm{KB} 2:=0.28 \pm 0.09 ; \mathrm{KB} 3=0.16 \pm 0.03$ and at $\mathrm{T} 2: \mathrm{KB} 1=0.79 \pm 0.23 ; \mathrm{KB} 2=0.61 \pm$ 0.18 ; KB3 $=0.39 \pm 0.09$ ). However, at $\mathrm{T} 4$, during full vitellogenesis, because of great interindividual differences, the effect was no longer significant. At spawning, the pattern was reversed since $\mathrm{T}$ was higher when dietary genistein increased. Significant differences were observed only between control and $1000 \mathrm{ppm}$ genistein treated fish (figure $3 \mathrm{c}$ ).

Plasma $11 \mathrm{KT}$ levels were low and did not vary between treatments except at T4. Generally in this species, this steroid is absent from the female plasma, but even in control fish, the $11 \mathrm{KT}$ plasma levels reached concentrations above $2 \mathrm{ng} / \mathrm{ml}$ at $\mathrm{T} 4$ and $\mathrm{T} 5$. In treated fish this rise was delayed and appeared only at T5 (figure 3d).

\section{Gonadotrophin and $17 \alpha, 20 \beta(\mathrm{OH})_{2}-P$ levels}

In males, plasma $\beta \mathrm{LH}$ levels were very low at T4 (below the assay detection limit of $0.1 \mathrm{ng} / \mathrm{ml}$ ) and at T5 (below $0.6 \mathrm{ng} / \mathrm{ml}$ ). For both $\beta \mathrm{FSH}$ and $\beta \mathrm{LH}$, no significant differences 
were detected between control and treated fish either at T4 or at T5. However the mean value of both hormones were consistently lower for the $500 \mathrm{ppm}$ genistein fed fish at these two sampling times (table 3).

In females, plasma $\beta$ FSH levels declined consistently between $\mathrm{T} 4$ and T5 only in genistein-fed fish. At T4, plasma $\beta$ FSH levels were significantly lower in the $1000 \mathrm{ppm}$ treated fish than in the control. At that time the plasma $\beta$ LH levels were very low (below 0.4 $\mathrm{ng} / \mathrm{ml}$ ). At spawning (T5), the $\beta \mathrm{LH}$ levels were much higher than at T4 but were consistently lower $(\alpha=0.05 \%)$ in genistein-fed fish (table 3).

In males, the pattern of changes in $17 \alpha, 20 \beta(0 \mathrm{H})_{2}-\mathrm{P}$ was comparable to those of $\beta \mathrm{FSH}$ and $\beta \mathrm{LH}$ (table 3). However, plasma $17 \alpha, 20 \beta(0 \mathrm{H})_{2}-\mathrm{P}$ levels in the $500 \mathrm{ppm}$ treated group were significantly lower than in control fish. In females, the changes in $17 \alpha 20 \beta(\mathrm{OH})_{2}-\mathrm{P}$ was comparable to plasma $\beta \mathrm{LH}$ levels. Although the difference was significant in $500 \mathrm{ppm}$ treated females $(\mathrm{p}<0.05)$, it was not in $1000 \mathrm{ppm}$ treated females.

\section{Gonadal development}

In males, at $\mathrm{T} 0$ the only stage that could be identified in the testis was spermatogonia. At T1, both spermatogonia of type 1 and 2 were distinguishable through histological observations. This corresponded to stage 1 (table 2). At T2, the analysis exhibited differences between the three groups. Briefly, it appeared that the more genistein in the diet the higher percentage of males at stage 4 and the lower percentage of males at stage 1, 2 and 3 (figure 4a). At T3 similar results were obtained although less distinctly (figure $4 \mathrm{~b}$ ). The highest percentage of males at T4 was recorded in the $1000 \mathrm{ppm}$ treated group whereas in this group there were no stage 3 males, although there were among control and $500 \mathrm{ppm}$ treated fish. However, as per the Fisher test of frequency comparison, the differences recorded were not significant. 
In females no effect of any treatment (presence or absence of genistein) could be identified. At T0 only very small oogonia cells were seen which were not distinguishable from the male cells. At T1, the larger cells observed were at stage 2 in all fish. At T2, females were essentially at stage 2 . At T3 all females had reached stage 3 since in all females small VTG granules were identified at the periphery of the bigger oocytes whereas the zona-radiata was already large and presented at least two distinct layers. No samples were withdrawn for microscopic observations at T4 and T5 (spawning period).

\section{Gamete quality}

Data on various parameters related to male gamete quality are presented in Table 5 . The percentage of male in spermiation on $29^{\text {th }}$ October (between $\mathrm{T} 4$ and T5) increased with genistein intake, although the difference was not significant. This concurs with the results obtained by histological analysis. The GSI measured after sperm collection was not modified either in control or in treated fish. The sperm volume collected at stripping increased significantly with genistein consumption. Spermatocrit was significantly decreased in trout fed diets with 1000 ppm of genistein. Sperm motility decreased significantly in fish fed diets with genistein (table 4).

When egg characteristics were compared, the only statistical differences were observed between \% of residual gonads after stripping in fish fed with 500 ppm and 1000 ppm genistein (table 5).

\section{Fecundity and fertilisation}

Fecundity and fertilisation rates in females from each group are presented in table 5. Evolution of spawning is presented in figure 5. At the first spawning date (17/12/97), only $10.5 \%$ of the fish spawned in the group fed $500 \mathrm{ppm}$ genistein against $21.05 \%$ in the group 
fed the control diet and $23.5 \%$ in the group fed $1000 \mathrm{ppm}$ genistein (Figure 5). Moreover, at this date, only $50 \%$ of the fish fed 500 ppm genistein yield viable eggs whereas $100 \%$ of fish of the other groups gave viable eggs. Throughout the spawning period, the percentage of spawning females in the 500 ppm fed group was always lower than in the other two groups. Over the total period of spawning, $100 \%$ of females of the control and the $1000 \mathrm{ppm}$ fed group ovulated against $79 \%$ of the females from the $500 \mathrm{ppm}$ fed group. Indeed, six females out of 19 did not ovulate and among them 3 were blocked at a previtellogenic stage and 3 were only delayed and would have probably spawned later on, after the experiment. There was no difference in fecundities. Moreover, although there was no difference in egg diameter between groups, the highest variability was observed of the $500 \mathrm{ppm}$ fed group (variation coefficient were $4.23,7.51$ and 5.60 for diet with 0,500 and 1000 ppm respectively). Fecundity was generally lower in 500 ppm fed fish. At the eyed stage, the different batches coming from the females fed the same diet were pooled and those of the worst spawns were eliminated. At that time the results obtained on embryo survival were not significantly different.

\section{DISCUSSION}

\section{Diets}

The choice of the dietary genistein levels was made in accordance with previous data showing that some soy products can contain up to $6000 \mathrm{ppm}$ genistein or $8000 \mathrm{ppm}$ of total phytoestrogens when daidzein was also considered (Mambrini et al., 1999).

$250 \mathrm{~g}$ of highly pure genistein were used in this experiment. Genistein (genistein) was incorporated as such in the diet whereas naturally it is present in plant by-products as glycoside, acetyl or malonyl derivatives (Anderson and Wolf, 1995). Indeed, we have been able to detect genistein in the plasma of fish fed diets containing soy protein concentrates at 
levels ranging from 20 to $250 \mathrm{ng} / \mathrm{ml}$ using the technique reported in Bennetau - Pelissero et al., (2000). Under such circumstances, since gut microflora in fish is considered as inefficient (Lesel, 1987), some hydrolysis must occur in the gut and probably in the stomach under the action of digestive enzymes and low $\mathrm{pH}$. This suggests that genistein is naturally deglycosylated and is absorbed into the blood stream. However the bioavailability of genistein with a diet enriched with either genistein or genistin (its glycoside derivative) remains to be investigated.

\section{Growth}

In this study, there was no effect of pure genistein on fish growth. In mammals, Stob, (1983) reported that phytoestrogens can alter appetite via an interaction at the level of central nervous system and thus can reduce daily weight increase. Our data suggest that, phytoestrogens or at least genistein even present at high levels in food but were not the compounds responsible for the alteration of growth, contrary to earlier observations of Mambrini et al., (1999) who found that high levels of dietary soy protein concentrates, rich in phytoestrogens led to decreased growth of rainbow trout.

\section{Cholesterol}

Plasma cholesterol levels in vitellogenic females and in males undergoing spermiogenesis were not affected by dietary treatments. These results are in contrast to those from studies in rats (Dodge et al., 1996; Kirk et al., 1998) showing that soy-protein based diet or phytoestrogens can lower cholesterol blood concentrations. In rainbow trout,, Kaushik et al., (1995) also showed that replacement of fish meals by soy by-products had a hypocholesterolemic effect. Either genistein is not the compound which, in soy, provokes cholesterol lowering in the rainbow trout, or that the lowering of cholesterol was due to the 
global decrease of cholesterol in the diet when fish meal (rich in cholesterol) was replaced by soybean protein concentrates (low in cholesterol).

\section{Endocrine parameters}

The group fed the fish-meal based diet exhibited normal steroid profile when compared to data obtained on fish when soy was only a minor component of fish diets (Hoar et al., 1983 ) and classic gonadotrophin profiles (Breton et al., 1998).

The interpretation of the effect of genistein must be done remaining that it is both an in vivo agonist and an antagonist of $\mathrm{E}_{2}$ (Adlercreutz, 1990). In vitro, this dual effect seems to be affected by the ratio between $\mathrm{E}_{2}$ and genistein at the target organ (Adlercreutz et al., 1995). A genistein/ $E_{2}$ ratio between 10 to 100 would lead to a competition for the estradiol receptor (ER) which fails to induce gene transcription; an anti-estrogenic effect is then observed (Verdeal et al., 1980). Below, the estrogenic effect of $E_{2}$ would mask genistein effect and above genistein exerts an overall estrogenic effect. This can be explained, at least partly, by the difference in affinity between $\mathrm{E}_{2}$ and genistein for the ER. It was recently shown in vitro, that genistein affinity is 50 times less that of $\mathrm{E}_{2}$ for rainbow trout ER (Latonnelle et al., 2000).

Other properties essentially demonstrated in mammals such as inhibition of prostaglandin H synthase (Degen, 1990), of protein tyrosine kinase (PTK) and of protein kinase C (PKC) (Osada et al., 1988), differential binding to ER $\alpha$ and ER $\beta$ (Kuiper et al., 1998 ; Miodini et al., 1999) or SBP binding (Bennetau - Pelissero et al., 1998) may play a part in vivo in the endocrine disruption observed here.

\section{Endocrine and VTG profiles in females}

At the beginning of the study ( $\mathrm{T} 1$ to $\mathrm{T} 2$ ), when females had low levels of circulating $\mathrm{E}_{2}$, genistein had an overall estrogenic effect shown by increased plasma VTG levels. 
Between previtellogenic to vitellogenic stages (T2 and T3), $\mathrm{E}_{2}$ levels rose and in the $500 \mathrm{ppm}$ treated fish, genistein has no estrogenic effect. Since in this group, fish were found to be blocked in previtellogenesis, it is likely that it is then that genistein exerted its preeminent negative effect on gametogenesis. Maestro et al., (1997) shown that both insulin and IGF stimulate PTK activity in early vitellogenic carp oocytes. Because genistein can act as a PTK inhibitor it could perturb this process and at least delay vitellogenesis and early yolk accumulation. Although, it remains to be seen whether the phenomenon observed in carp occurs in trout, this could explain why some fish (3 out of 19) did not undergo yolk accumulation in trout fed 500 ppm genistein.

During vitellogenesis (T3 to $\mathrm{T} 4$ ), plasma $\mathrm{E}_{2}$ concentration is such that it probably overcame the effect of genistein.

Between $\mathrm{T} 4$ and $\mathrm{T} 5$, when $\mathrm{E}_{2}$ levels returned to low values, genistein exerted its estrogenic activity as revealed by high VTG levels. The presence of high amounts of ER would then have led to a large estrogenic effect.

Data obtained in females for $11 \mathrm{KT}$, and probably $\mathrm{T}$ levels at spawning can also be interpreted as reflecting a delayed steroidogenesis and consequently VTG synthesis in genistein-fed fish. These results can be compared with those obtained in sea bass (Kah et al., 1994), where a delay of peak appearance of $\mathrm{T}$ was observed when fish were fed diet containing $23.22 \mathrm{~g} / 100 \mathrm{~g}$ of soy compared to a diet containing $13.93 \mathrm{~g} / 100 \mathrm{~g}$ of soy. It must be noted that the levels of steroid measured using the $11 \mathrm{KT}$ antiserum may reflect the levels of other androgens since the $11 \mathrm{KT}$ antibody was shown to cross-react at $6.8 \%$ with $\mathrm{T}$, at $6.3 \%$ with $11 \beta$-hydroxytestosterone and at $3.5 \%$ with $5 \alpha$-DHT.

Genistein effect on FSH levels at T4 and T5 in females may be explained as an estrogenic effect. Indeed, genistein as estrogen-like compound can exert an estrogenic negative feed-back on FSH release (Saligaut et al., 1998). As regards LH, there are at least 
three possible scenarios. First, it can be considered that genistein, acting as estradiol prevents LH release via a dopamine interaction (Linard et al., 1995). Secondly, according to Melamed et al., (1998) PKC is involved in GnRH release and consequently in LH secretion. Genistein could then have impaired GnRH release and consequently LH release at spawning, through its PKC inhibitory effect. Thirdly, GABA induces GnRHII in gold fish brain through GABAA receptors (Trudeau et al., 1993) and genistein was recently shown to be a specific inhibitor of GABAA receptors in rats (Huang et al., 1999). There are thus many ways by which genistein could inhibit FSH and LH release. The complex interactions may explain why the reduction is not clearly dose-dependant. The results obtained in this study may be correlated to previous work by Kah et al., (1994) showing that a diet containing $23.22 \mathrm{~g} / 100 \mathrm{~g}$ of soybean meal reduces pituitary GnRH when compared to a diet containing $13.93 \mathrm{~g} / 100 \mathrm{~g}$. The authors attributed this effect to the ratio protein/carbohydrate. However, genistein might have been present in these diets and may have been the compound acting on this mechanism.

Because LH was significantly reduced in plasma of fish fed diets containing genistein, lower plasma levels of $17 \alpha, 20 \beta(\mathrm{OH})_{2}-\mathrm{P}$, maturation inducing steroid, synthesised under $\mathrm{LH}$ stimulation and allowing egg laying and sperm release (Zohar et al., 1986), were expected.

\section{Endocrine and VTG profiles in males}

In males, at the beginning of the study, $\mathrm{E}_{2}$ levels were very low and genistein acted as an estrogen, with a prolonged VTG synthesis. However, the low level of VTG synthesis in males was probably due to low levels of hepatic ER. Indeed, in vitro, phytoestrogens, including genistein, were less potent in males than in females to induce expression of both rtER mRNA and rtVTG mRNA (Bennetau - Pelissero et al., 1998). In the latter study, females already had levels of rtER mRNA of $14 \mathrm{pg} / \mathrm{ng}$ of total mRNA whereas in males it was less than $1 \mathrm{pg} / \mathrm{ng}$ of total mRNA. Only concentrations of $10 \mu \mathrm{M}$ of genistein induced rtER and 
rtVTG mRNA synthesis in males in a 24 hours exposure. It is likely that the circulating levels of genistein were lower than these concentrations; thus the induction of both ER and VTG synthesis in male was low.

The present data suggest that genistein led to accelerated spermatogenesis. Under such circumstances, a degradation of sperm motility as well as a decreased in sperm concentration can be expected at spawning (Lahnsteiner et al., 1998). Further, $\mathrm{LH}$ and $17 \alpha 20 \beta(\mathrm{OH})_{2} \mathrm{P}$ were demonstrated to induce testicular hydration in European Sea bass (Mylonas et al., 1997). Then, if spermatogenesis was accelerated under genistein, testis were ready earlier in fish under genistein and their time of exposure to both $\mathrm{LH}$ and $17 \alpha 20 \beta(\mathrm{OH})_{2} \mathrm{P}$ could be responsible for the decrease in sperm count and increase in sperm volume. This explanation may not be the only one. At full spermatogenesis (T4) the $\mathrm{E}_{2}$ profile exhibits an increase in control fish, but not in genistein fed fish. This rise is commonly interpreted in males as an aromatisation of androgens into estrogens at the hypothalamic and pituitary level, inducing LH release and maturation (Fostier et al., 1979). However, this peak seems high and may not only be due to this aromatisation process. Because, fish from all groups reached spermiation and the proportion of fish ready to reproduce was higher on the 29/10/97 in treated groups, it can be supposed that this $\mathrm{E}_{2}$ rise did occur but was not seen under the sampling frequency used. The VTG rise observed at T4 in all treated fish agrees with this interpretation. The highly significant rise in plasma $\mathrm{E}_{2}$ in control males at $\mathrm{T} 4$ is followed by a decrease at $\mathrm{T} 5$. This decrease can be due both to a decreased aromatase activity in the brain or to a disappearance of a common precursor of $\mathrm{T}$ and $\mathrm{E}_{2}$ since $\mathrm{T}$ at $\mathrm{T} 5$ is also reduced.

The acceleration of spermatogenesis, supported by gonadal examination at $\mathrm{T} 2$, by $\mathrm{E}_{2}$ and VTG profiles as well as by sperm characteristics, can be due, under genistein exposure, to an estrogenic effect of genistein because endogenous estradiol was very low. Indeed, in amphibians, one of the consequences of a slight estrogen exposure was acceleration of 
spermatogenesis (Cobellis et al., 1999). The estrogenic effect of genistein could also result in a similar effect in trout, as suggested by the data of Thomas (2000). The differences observed in $\mathrm{T}$ and $11 \mathrm{KT}$ plasma levels (figure2c and $2 \mathrm{~d}$ ) at spawning also suggest an acceleration of spermatogenesis. At spawning, the effect of genistein on LH release as proposed for females is also possible in males. The inhibition of LH release, although not significant, can be correlated with the significantly decreased plasma $17 \alpha, 20 \beta(\mathrm{OH})_{2}-\mathrm{P}$. The lack of significance might be due to the low number of fish analysed for LH measurements (10 males and 10 females only).

In both sexes, plasma testosterone levels were significantly decreased in genistein-fed fish although spermatogenesis was accelerated in males. Indeed, if spermatogenesis was accelerated with genistein exposure, an increase in $\mathrm{T}$ levels would have been expected. However, plasma $\mathrm{T}$ levels and those of other steroids reflect both secretion by the gonad and elimination by specific hepatic enzymes. Among them, T6 $\beta$-hydroxylase known to play a major role, the activity of which has been found to increase when fish were fed a soy enriched diet (Cravedi et al., 1997). When T levels rose the effect of genistein on T lowering was no more significant. This can possibly be due to enzyme substrate saturation. Decreased plasma $\mathrm{T}$ levels by estrogenic endocrine disruptors has been reported in carp captured in polluted rivers (Folmar et al., 1996) and in alligators submitted to estrogenic pollutants (Guillette et al., 1999), although the mechanisms involved are not clear.

\section{Reproductive efficiency}

Assessed both in terms of gamete quality and fecundity, the $500 \mathrm{ppm}$ treated group presented the poorest characteristics both in males and females. Overall, the effect of genistein can be summarised as that reproduction was delayed in females and accelerated in males. It is possible to speculate on the stage of oogenesis when the effect seems to be the strongest. In 
the $1000 \mathrm{ppm}$ treated fish, there is a decrease in GTHs and $17 \alpha 20 \beta(\mathrm{OH})_{2} \mathrm{P}$ at the end of gametogenesis ; however this does not seem to affect spawning adversely. In 500 ppm treated fish, although plasma $\mathrm{LH}$ and $17 \alpha 20 \beta(\mathrm{OH})_{2} \mathrm{P}$ levels were decreased the greatest effect seems to be an impairment in the transition of the gonad from a previtellogenic stage to vitellogenesis. This is supported since among the 19 females of this group 3 did not start vitellogenesis, 3 others started vitellogenesis but probably later and did not spawn by the end of the trial. Two females among those which spawned gave poor quality laying with very low survival rates at the eyed stage (about $0 \%$ ). In addition, the heavier residual gonad was found in this group. This probably reflects that, in the spawning females, the eggs were not all synchronised by the time of spawning. In males, the acceleration of spermatogenesis seems to occur at early spermatogenesis as revealed by histology. Although the frequency analysis did not reveal significant differences, similar results obtained with soy based diets in male rainbow trout (unpublished results) also suggest the same effect. The slight GTHs and $17 \alpha 20 \beta(\mathrm{OH})_{2} \mathrm{P}$ impairment could also reduce male reproductive performance in the $500 \mathrm{ppm}$ treated group.

This study showed that genistein, a natural endocrine disruptor of dietary origin, has some effects on the reproductive performances of the rainbow trout at the doses tested. No clear dose dependant response were recorded, with doses of $500 \mathrm{ppm}$ having more deleterious effects on reproductive efficiency than doses of $1000 \mathrm{ppm}$. Data show that the effect of genistein on the gonadal development depends greatly upon the stage and the endogenous estrogen secretion.

In fish farms trout reared until $250 \mathrm{~g}$ mean weight are likely not to be influenced by soy isoflavone in their diet (no growth disruption in this trial). In triploid fish the effect of 
isoflavones remain to be tested but since reproduction is not completed it can be expected that soy based diet would not have major effects.

Finally, even if genistein has only minor effects on the trout reproductive performances phytoestrogens interactions with steroids have to be considered in spawners especially when reproductive physiology criteria are analysed in endocrine approaches.

ACKNOWLEDGEMENTs : This work was supported by a grant from the French Ministry of Agriculture and by the ENITA of Bordeaux. We want to specially thank Frederic Vallée, Frederic Terrier, Franck Sandres, Yves Hontang, Patrick Maunas, and Jean-Paul Flouriot for their valuable assistance during growth trials and samplings. We would like to thank Dr Fostier from Rennes (INRA, France) for the $17 \alpha, 20 \beta(\mathrm{OH})_{2}-\mathrm{P}$ antibody, Drs Carillo and Zanuy (CSIC,ITATS, Spain) for the $\mathrm{E}_{2}$ antibody, and Dr Kime (Univ. Sheffield, UK) for the T antibody. 


\section{REFERENCES}

Adlercreutz, H. (1990). Western diet and western diseases : some hormonal and biochemical mechanisms and associations. Scand. J. Clin. Lab. Invest. 50, 3-23.

Adlercreutz, H., Goldin, B. R., Gorbach, S. L., Höckerstedt, K. A. V., Watanabe, S., Hämäläinen, E. K., Markkanen, M. H., Mâkelä, T. H., Wähälä, K. T., Hase, T. A. and Fotsis, T. (1995) Soybean phytestrogen Intake and cancer risk. J. Nutr. 125, 757S-770S. Akiyama, T., Ishida, J., Nakagawa, S., Ogawara, H., Watanabe, S., Itoh, N., Shibuya, M., Fukami, Y. (1987). Genistein, a specific inhibitor of tyrosine-specific protein kinases. $J$. Biol. Chem. 262, 5592-5595.

Anderson, R. L. and Wolf, W. J. (1995). Compositional changes in trypsin inhibitors, phytic acid, saponins and isoflavones related to soybean processing. J. Nutr. 125, 581S-588S.

Awoniyi, C. A., Roberts, D., Veeramachaneni, D. N., Hurst, B. S. Tucker, K. E., Schlaff, W. D. (1998). Reproductive sequelae in female rats after in utero and neonatal exposure to the phytestrogen genistein. Fertil. Steril. 70, 440-7.

Baker, W., Chadderton, J., Harborne, J., Ollis, W. D. (1953). A new synthesis of isoflavone. Part I. J. Chem. Soc. 1852-1860.

Bennetau - Pelissero, C ., Flouriot, genistein ., Valotaire, Y., Sumpter, J. P and Le Menn, F. (1998). Induction of rainbow trout estradiol receptor (rtER) mRNA and vitellogenin (rtVTG) mRNA by phytoestrogensin hepatocyte cultures. Ann. New York Acad. Sci. 839, 600-601.

Bennetau - Pelissero, C., Kaushik, S., Sumpter, J. P., Fostier, A., Le Gac, F., Valotaire, Y., Davail - Cuisset, B., and Le Menn, F. (1998). Soy and phytestrogens. Their effects on vitellogenesis and steroid endocrinology in the rainbow trout and the Siberian sturgeon. In vivo and in vitro approaches. Bull. Fra. Pêche Pisci. 350-351, 571-583.

Bennetau - Pelissero C., Le Houérou C., Lamothe V., Le Menn F., Babin P., Bennetau B. 2000. Synthesis of haptens and conjugates for ELISAs of phyto-estrogens. Development of the immunological tests. J. Agric. Food. Chem.48, 305-311.

Bon, E., Barbe, U., Nunez - Rodriguez, J., Cuisset, B., Pelissero, C., Sumpter, J.P. and Le Menn, F. (1997). Plasma vitellogenin levels during the annual reproductive cycle of the female rainbow trout (Oncorhynchus mykiss): Establishment and validation of an ELISA. Comp. Biochem. Physiol. 117B, 75-84.

Breton, B., Govorum, M. and Mikolajczyk, T. (1998). GTHI and GTHII secretion profiles during the reproductive cycle in female rainbow trout : relationship with pituitary 
responsiveness to GnRH-A stimulation. Gen. Comp. Endocrinol. 11, 38-50.

Casanova, M., You, L., Gaido, K. W., Archibeque-Engle, S., Janszen, D. B., Heck, H. A., (1999). Developmental effects of dietary phytoestrogensin Sprague-Dawley rats and interactions of genistein and daidzein with rat estrogen receptors alpha and beta in vitro. Toxicol. Sci. 51, 236-44.

Cobellis, genistein., Pierantoni, R., Minucci, S., Pernas-Alonso, R., Meccariello, R. and Fasano, S. (1999). c-fos activity in Rana esculenta testis: seasonal and estradiol-induced changes. Endocrinology 140, 3238-3344.

Cravedi, J. P. (1997). Effects of soybean diet on monooxygenase and transferase enzyme activities in rainbow trout. In «Third International Symposium on Research for Aquaculture : Fundamental and applied aspects. Barcelona, Spain, 24-27 August 1997, » p.190.

Cuisset, B., Fostier, A., Williot, P., Bennetau - Pelissero, C. and Le Menn, F. (1995). Occurrence of 11-ketotestosterone in Siberian sturgeon, (Acipenser baeri Brandt) maturing females. Fish Physiol. Biochem. 14, 313-322.

Degen, genistein. H. (1990). Interaction of phytoestrogens and other environmental estrogens with prostaglandine synthase in vitro. J. Steroid. Biochem. 35, 473-480

Dodge, J. A., Glasebrook, A.L., Magee, D.E., Phillips, D.L., Sato, M., Short, L.L. and Bryant, H.U. (1996). Environmental estrogens : effects on cholesterol lowering and bone in the ovariectomized rat. J. Steroid Biochem. Mol. Biol. 59, 155-161.

Farnsworth, N. R., Bingel, A. S., Cordell, genistein. A., Crane, F. A. and Fong, H. H. S. (1975). Potential value of plants as sources of new antifertility agents II. J. Pharm. Sci. 64, 717-754.

Folmar, L. C., Denslow, N. D., Rao, V., Chow, M., Crain, D. A., Enblom, J., Marcino, J. and Guillette, L. J. Jr. (1996). Vitellogenin induction and reduced serum testosterone concentrations in feral male carp (Cyprinus carpio) captured near a major metropolitan sewage treatment plant. Environ. Health Perspect. 104, 1096-101.

Fostier, A., Weil, C., Terqui, M., Breton, B. and Jalabert, B. (1979). Plasma estradiol and gonadotropin during ovulation in the rainbow trout (Salmo gairdneri R.) Ann. Biol. Anim. Bioch. Biophys. 18, 929-936.

Govorum, M., Chyb, J. and Breton, B. (1998). Immunological cross-reactivity between rainbow trout GTHI and GTHII and their $\alpha$ and $\beta$ subunits: Application to the development of specific radioimmunoassays. Gen. Comp. Endocr. 111, 28-37. 
Guillette, L. J. Jr, Brock, J. W., Rooney, A. A. and Woodward, A. R. (1999). Serum concentrations of various environmental contaminants and their relationship to sex steroid concentrations and phallus size in juvenile American alligators. Arch. Environ. Contam. Toxicol. 36, 447-55.

György, P., Murata, K. and Ikehata, H. (1964). Antioxidant isolated from fermented soybeans (Tempeh). Nature 203, 870-872.

Hoar, W. S., Randall, D. J. and Donaldson, E. M. (1983). Fish physiology IX. Academic Press New York.

Hopert, A. C., Beyer, A., Frank, K., Strunck, E., Wunsche, W. and Vollmer, genistein. (1998). Characterization of estrogenicity of phytoestrogensin an endometrial-derived experimental model. Environ. Health Perspect. 106, 581-586.

Huang, R. Q., Fang, M. J. and Dillon, genistein. H. (1999). The tyrosine kinase inhibitor genistein directly inhibits GABAA receptors. Brain Res. Mol. Brain Res. 67, 177-183.

Hughes, C. L. Jr. (1988).Effects of phytoestrogens on GnRH-induced luteinizing hormone secretion in ovariectomized rats. Reprod. Toxicol. 1, 179-181.

Kah, O., Zanuy, S., Pradelles, P., Cerda, J. L. and Carrillo, M. (1994).An enzyme immunoassay for salmon gonadotropin-releasing hormone and its application to the study of the effects of diet on brain and pituitary GnRH in the sea bass, Dicentrarchus labrax. Gen. Comp. Endocrinol. 95, 464-474.

Kaplanski, O., Shemesh, M. and Berman, A. (1981). Effects of phytoestrogens on progesterone synthesis by isolated bovine granulosa cells. J. Endocrinol. 89, 343-348.

Kaushik, S. J., Cravedi, J. P., Lalles, J. P., Sumpter, J., Fauconneau, B. and Laroche, M. (1995) Partial or total replacement of fish meal by soybean protein on growth, protein utilisation, potential estrogenic or antigenic effects, cholesterolemia and flesh quality in rainbow trout, Oncorhynchus mykiss. Aquaculture 133, 257-274.

Kirk, E. A., Sutherland, P., Wang, S.A., Chait, A. and Le Bœuf, R. C. (1998). Dietary isoflavones reduce plasma cholesterol and arterosclerosis in C57BL/6 mice but not LDL receptor-deficient mice. J. Nutr. 128, 954-959.

Kuiper, genistein. genistein., Lemmen, J. genistein., Carlsson, B., Corton, J. C., Safe, S. H., van der Saag, P. T., van der Burg, B. and Gustafsson, J. A. (1998). Interaction of estrogenic chemicals and phytoestrogens with estrogen receptor beta. Endocrinology 139, $4252-4263$.

Labbe, C. and Maisse, genistein. (1996). Influence of rainbow trout thermal acclimation on 
sperm cryopreservation : relation to change in the lipid composition of the plasma membrane. Aquaculture 145, 281-294.

Lahnsteiner, F., Berger, B., Weismann, T. and Patzner, R. A. (1998). Determination of semen quality of the rainbow trout, Oncorhynchus mykiss, by sperm motility, seminal plasma parameters and spermatozoal metabolism. Aquaculture 163, 163-181.

Latonnelle, K., Bennetau - Pelissero, C., Fostier, A. and Le Menn, F. (2000). Affinity of estradiol receptors from rainbow trout hepatocytes for phytestrogens. In « 6th Interernational Symposium of Reproductive Physiology of Fish. Bergen Norway, July 4-9 1999, » p.385.

Levy, J. R., Faber, K. A., Ayyash, L. and Hughes, C. L. Jr. (1995). The effect of prenatal exposure to the phytestrogen genistein on sexual differentiation in rats. P.S.E.B.M. 208, 60-66.

Lesel, R. (1987). Les communautés bacteriennes hébergées par la truite arc-en-ciel Salmo gaidneri Ridcharson, facteur de variations et fonctions. Thèse d'Etat $\mathrm{n}^{\circ}$ 924, Bordeaux, France : University Bordeaux I.

Linard, B., Bennami, S. and Saligaut, C. (1995). Involvement of estradiol in a catecholamine inhibitory tone of gonadotropin release in the rainbow trout (Oncorhynchus mykiss). Gen. Comp. Endocrinol. 99, 192-196.

Maestro, M. A., Mendez, E., Parrizas, M. and Gutierrez, J. (1997). Characterization of insulin and insulin-like growth factor-I ovarian receptors during the reproductive cycle of carp (Cyprinus carpio). Biol. Reprod. 56, 1126-32.

Mambrini, M., Roem, A. J., Cravédi, J. P., Lallès, J. P. and Kaushik, S. J. (1999). Effects of replacing fish meal by soy protein concentrate and of DL-methionin supplementation in high energy extruded diets on growth and nutrient utilisation of Rainbow trout, Oncorhynchus mykiss. J. An. Sci. 77, 2990-2999.

Martin, M. E., Haourigui, M., Pelissero, C., Bennassayag, C. and Nunez, E. (1995). Interactions between phytoestrogens and human sex steroid binding protein. Life science 58, 429-436.

Martin, P. M., Horwitz, K. B., Ryan, D. S. and McGuire, W. L. (1978). Phytestrogen interaction with estrogen receptors in human breast cancer cells. Endocrinology 103, $1860-1867$.

Martojas, R. and Martojas, M. (1967) Initiation aux techniques de l'histologie animale. Masson et Cie Eds, France. 
Melamed, P., Rosenfeld, H., Elizur, A. and Yaron, Z. (1998). Endocrine regulation of gonadotropin and growth hormone gene transcription in fish. Comp. Biochem. Physiol. Part C 119, 325-338.

Milligan, S. R., Balasubramanian, A. V. and Kalita, J. C. (1998). Relative potency of xenobiotic estrogens in an acute in vivo mammalian assay. Environ. Health Perspect. 106, 23-26.

Miodini, P., Fioravanti, L., Di Fronzo, genistein. and Cappelletti, V. (1999). The two phytoestrogens genistein and quercetin exert different effects on estrogen receptor function. Br. J. Cancer 80, 1150-1155.

Mylonas, C. C., Scott, A. P., Vermeirssen, E. L. and Zohar, Y. (1997). Changes in plasma gonadotropin II and sex steroid hormones, and sperm production of striped bass after treatment with controlled-release gonadotropin-releasing hormone agonist-delivery systems. Biol. Reprod. 57, 669-675.

Osada, H., Magae, J., Watanabe, C. and Isono ; K. (1988). Rapid screening method for inhibitors of protein kinase C. J. Antibiot. 41, 925-930.

Pelissero, C., Bennetau, B., Babin, P., Le Menn, F. and Dunoguès, J. (1990). The estrogenic activity of certain isoflavones in the Siberian sturgeon Acipenser baeri. J. Steroid. Biochem. Molec. Biol. 38, 293-299.

Pelissero, C., Flouriot, genistein., Foucher, J. L., Bennetau, B., Dunoguès, J., Le Gac, F., Sumpter, J. P. (1993). Vitellogenin synthesis in hepatocyte culture, an in vitro test for the estrogenic potency of chemicals. J. Steroid. Biochem. Molec. Biol. 44, 263-272.

Pelissero, C., Lenczowski, M., Chinzi, D., Sumpter, J. P. and Fostier, A. (1996) Effects of flavonoids on aromatase activity, an in vitro study. J. Steroid. Biochem. Molec. Biol. 57, 215-223.

Pelter, A., Ward, R. S. and Bass, R. J. (1978). The carbon-13 nuclear magnetic resonance spectra of isoflavones. J. C. S. Perkin I 666-668.

Pike, A. C., Brzozowski, A. M., Hubbard, R. E., Bonn, T., Thorsell, A. genistein., Engstrom, O., Ljunggren, J., Gustafsson, J. A. and Carlquist, M. (1999). Structure of the ligandbinding domain of estrogen receptor beta in the presence of a partial agonist and a full antagonist. EMBO J. 18, 4608-4618.

Saligaut, C., Linard, B., Mananos, E. L., Breton, B. and Govorum, M. (1998). Realease of pituitary gonadotrophins GTH I and GTH II in the rainbow trout (Oncorhynchus mykiss) : modulation by estradiol and catecholamines. Gen. Comp. Endocrinol. 109, 
302-309.

Setchell K. D. R. (1985). Naturally occurring non-steroidal estrogens of dietary origin. In «Estrogens in the environment Vol II » (J. A. McLachlan, Ed), p.69-85. New York: Elsevier.

Setchell K. D. R. and Cassidy A. (1999) Dietary isoflavones: Biological effects and relevance to Human Health. J. Nutr. 129, 758S-767S.

Stob M. (1983) Naturally occurring food toxicants : estrogens. Handbook of Naturally Occurring Food Toxicants. M. Rechcigl Jr Ed. CRC Press Inc, Boca Raton Florida. 81 100.

Thomas, P. (2000) Nuclear and membrane steroid receptors and their functions in teleost gonads. In « 6th International Symposium of Reproductive Physiology of Fish, Bergen, Norway, 4-9 July 1999, » p.149-156.

Torbjorn, L. (1995). Metabolism of estrogenic isoflavones in domestic animals. P.S.E.B.M. 208, 33-39.

Trudeau, V. L., Sloley, B. D. and Peter, R. E. (1993). GABA stimulation of gonadotropin-II release in goldfish : involvement of GABAA receptors, dopamine, and sex steroids. Am. J. Physiol. 265, R348-R355.

Verdeal, K., Brown, R. R., Richardson, T. and Ryan, D. S. (1980). Affinity of phytoestrogens for estradiol - binding proteins and effect of coumestrol on growth of 7, 12Dimethylbenz[a]-anthracene - induced rat mammary tumors. J.N.C.I. 64, 285-290.

Waltz, E. (1931). Isoflavan und saponin-glucoside is soja hispida. Justus Liebig's Annalen Chemie 489, 118-155.

Zohar, Y., Breton, B. and Fostier, A. (1986). Short-term profiles of plasma gonadotropin and $17 \alpha$-hydroxy,20 $\beta$-dihydroprogesterone levels in the female rainbow trout at the periovulatory period. Gen. Comp. Endocrinol. 64, 189-198. 


\section{Figure and Table Captions}

Figure 1. Chronology of sample times

Figure 2. Steroid profiles in male rainbow trout submitted to KB1 : control fish-meal based diet, KB2 :diet with 500 ppm genistein, KB3 : diet with 1000 ppm genistein. Sample times are presented in figure 1. Values are means of 20 measurements; bars are sem, * indicates a significant difference at $\alpha=0.05$.

Figure 3. Steroid profiles in male rainbow trout submitted to KB1 : control fish-meal based diet, KB2 :diet with 500 ppm genistein, KB3 : diet with 1000 ppm genistein. Sample times are presented in figure 1. Values are means of 20 measurements; bars are sem, * indicates a significant difference at $\alpha=0.05$.

Figure 4. Frequency distribution of testis developmental stages in males submitted to KB1 : control fish-meal based diet, KB2 : with 500 ppm genistein, KB3 : with 1000 ppm genistein. The significance of the stages is given in table 3. For each diet 20 fish were considered at each sample time.

Figure 5. Performance of spawning of female rainbow trout submitted to KB1 : control fish meal based diet, KB2 : with 500 ppm genistein and KB3 : with 1000 ppm genistein. Value sharing a common letter are significantly different; at $\alpha=0.1$.

Table 3. KB1 is a control fish-meal based diet, KB2 is a diet with 500 ppm genistein, KB3 is a diet with 1000 ppm genistein. For GTHs values are means \pm sem of 10 measurements, for $17 \alpha, 20 \beta(\mathrm{OH})_{2}-\mathrm{P}$ values are means \pm of 19 measurements.

Table 4. KB1 is a control fish-meal based diet, KB2 is a diet with 500 ppm genistein, KB3 is a diet with 1000 ppm genistein. Values are means of 19 males \pm sem.

Table 5. KB1 is a control fish-meal based diet, KB2 is a diet with 500 ppm genistein, KB3 is a diet with 1000 ppm genistein. Values are means of 19 males \pm sem. 
746
Figure 1.

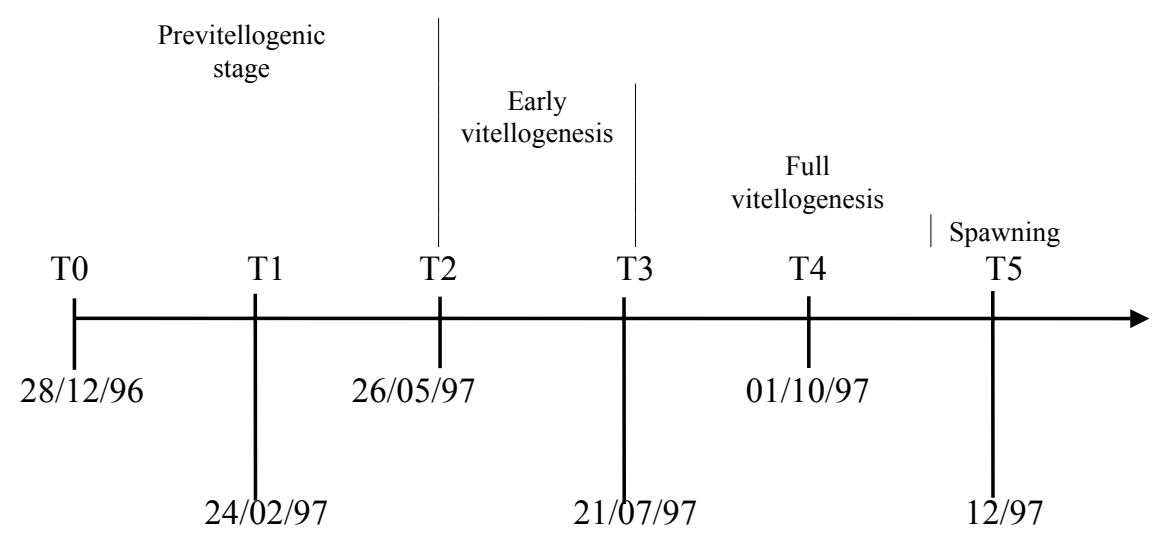


Figure 2

$2 a$ Estradiol in males

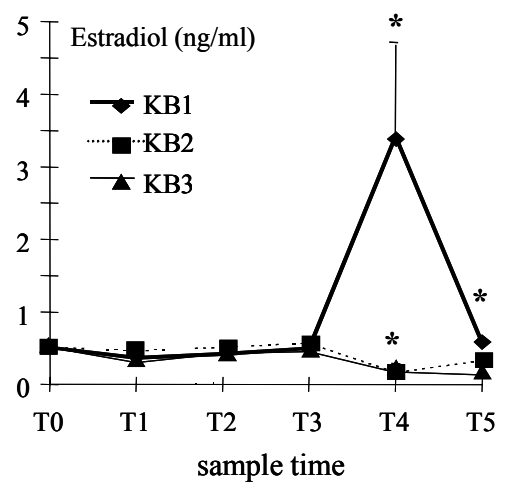

Vitellogenin in males

2b

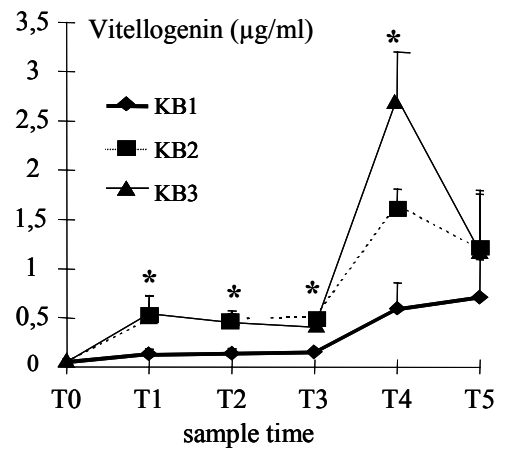

Testosterone in males

2c 60 Testosterone (ng/ml)

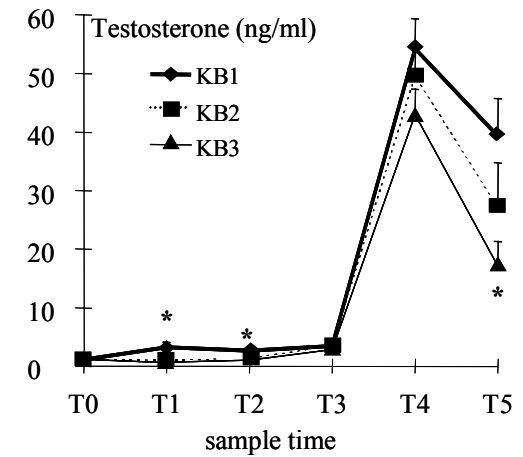

11-Ketotestosterone in males

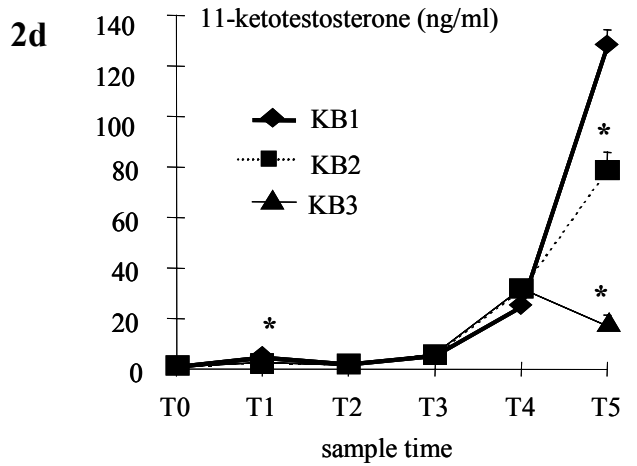


Figure 3

$3 \mathbf{a}$ Estradiol in females

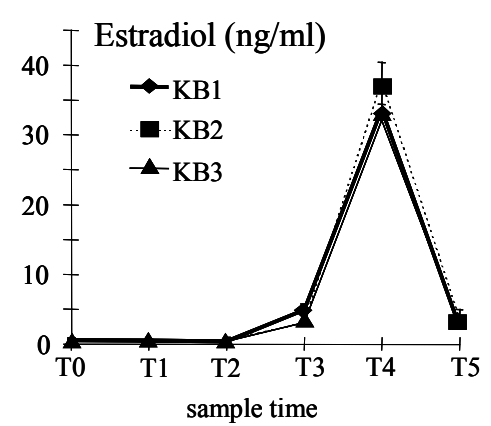

Vitellogenin in females

3b 251000 Vitellogenin $(\mu \mathrm{g} / \mathrm{ml})$

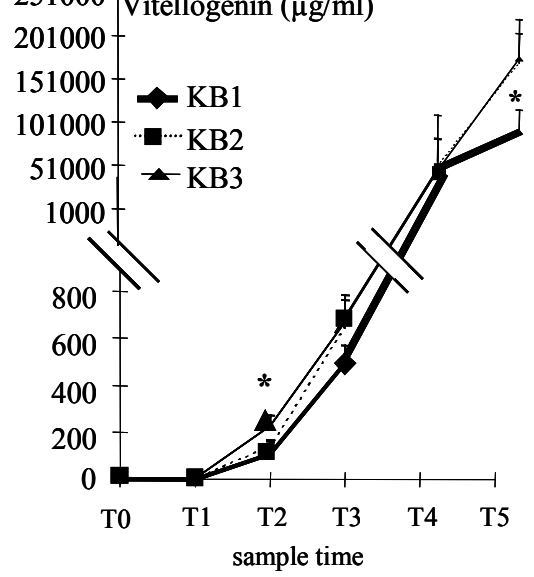

$3 c$

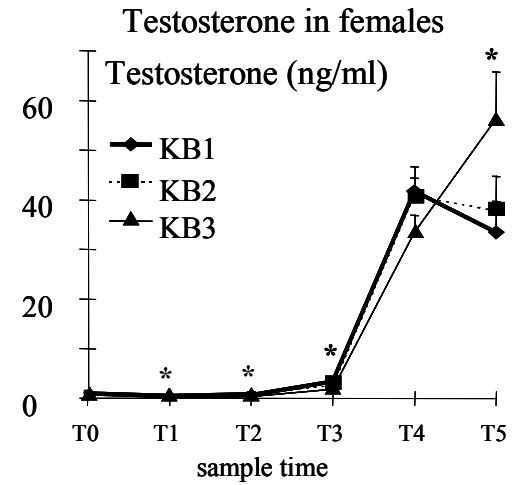

3d

11-Ketotestosterone in females

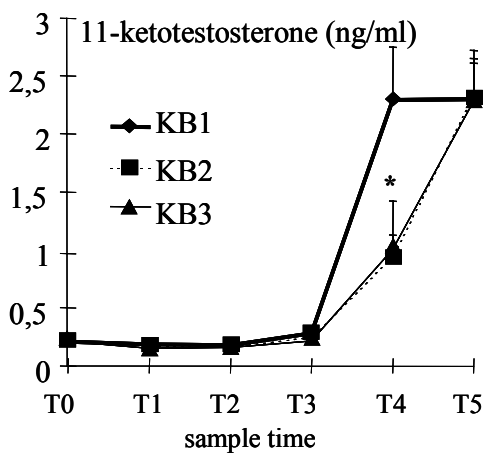


Figure 4

Frequence distribution

of testis development at T2

$4 a$

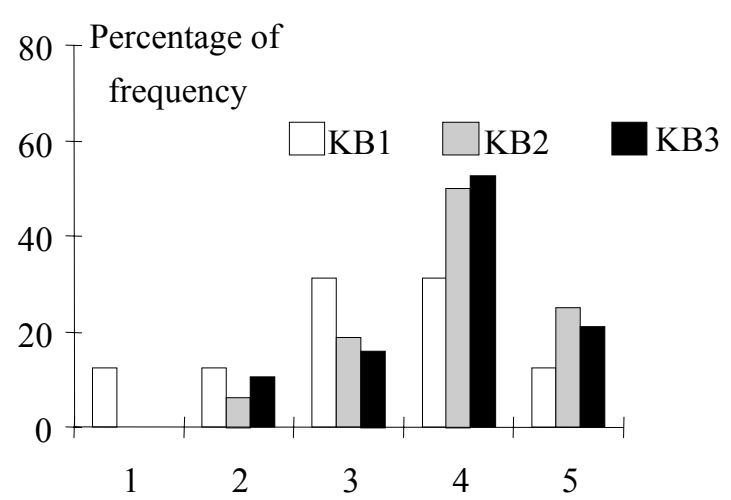

Gonadal stages

Frequency distribution

of testis development at T3

4b

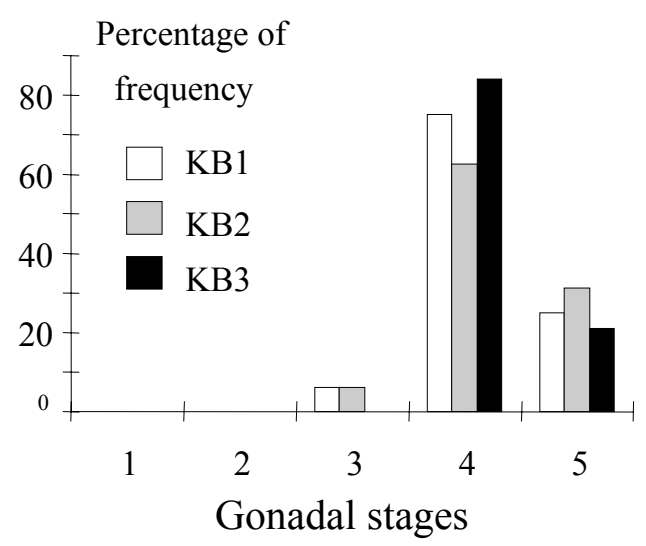


Figure 5

850

851

Evolution of spawning during the spawning period

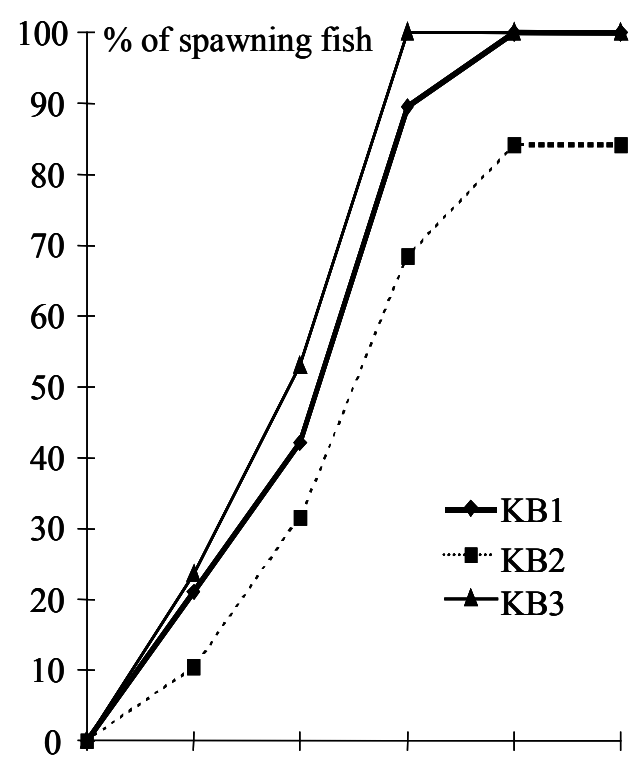

01-déc 17-déc 30-déc 12-jan 27-jan 10-fév Dates 